\title{
Data report: strontium isotope analyses of pore fluids from the CRISP-A transect drilled during Expeditions 334 and $344^{1}$
}

\author{
Nathan Ross, ${ }^{2}$ Marta E. Torres, ${ }^{2}$ Brian A. Haley, ${ }^{2}$ Evan A. Solomon, ${ }^{3}$ and Miriam Kastner ${ }^{4}$
}

\section{Chapter contents}

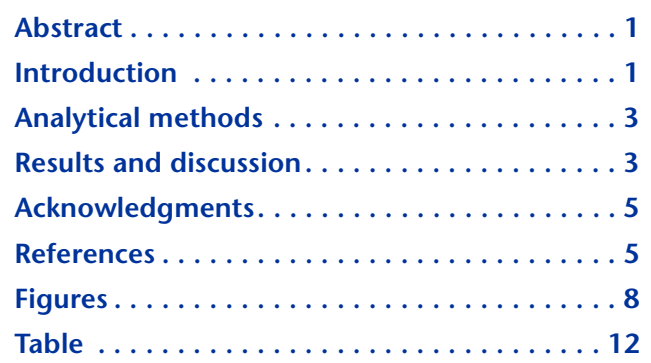

'Ross, N., Torres, M.E., Haley, B.A., Solomon, E.A., and Kastner, M., 2015. Data report: strontium isotope analyses of pore fluids from the CRISP-A transect drilled during Expeditions 334 and 344. In Harris, R.N., Sakaguchi, A., Petronotis, K., and the Expedition 344 Scientists, Proc. IODP, 344: College Station, TX (Integrated Ocean Drilling Program). doi:10.2204/iodp.proc.344.201.2015

${ }^{2} 104$ CEOAS Administration Building, Oregon State University, Corvallis OR 97331, USA.

Correspondence author:

mtorres@coas.oregonstate.edu

${ }^{3}$ School of Oceanography, University of

Washington, Seattle WA 98195, USA.

${ }^{4}$ Scripps Institution of Oceanography, University of California, San Diego, La Jolla CA 92093-0212, USA.

\section{Abstract}

We report on the Sr isotopic composition of pore fluids recovered during Integrated Ocean Drilling Program Costa Rica Seismogenesis Project Expeditions 334 and 344. Pore fluid samples were acidified and loaded directly onto columns containing EICHROM SrSpec resin, followed by analyses using a NU multicollector inductively coupled plasma-mass spectrometer at the Keck Collaboratory, Oregon State University.

Sites drilled on the upper plate exhibited a decrease in the ${ }^{87} \mathrm{Sr} /{ }^{86} \mathrm{Sr}$ ratio to values as low as 0.70762 in the upper $200-300 \mathrm{~m}$ of the sediment column, suggesting the role of ash alteration. The unconformity between the slope sediment sequence and underlying framework rock, sampled at Sites U1378-U1380, is characterized by intense fracturing. The fluids sampled within the unconformity at these sites have ${ }^{87} \mathrm{Sr} /{ }^{86} \mathrm{Sr}$ ratios ranging from 0.70834 to 0.70844 .

Fluids sampled from the incoming plate sediment show evidence of ash alteration and carbonate diagenesis, but the deepest sediment here may also be modified by diffusion of fluids from the underlying oceanic crust. Intense carbonate recrystallization in the lower $66 \mathrm{~m}$ of Site U1414 results in Sr concentrations that are almost an order of magnitude higher than those measured at the base of Site U1381. The deepest pore fluid sample measured at both Sites U1381 and U1414 has a ${ }^{87} \mathrm{Sr} /{ }^{86} \mathrm{Sr}$ ratio of 0.7086 .

The strontium systematics in this margin, used in the context of other ongoing studies, may be used to unravel processes at this margin, such as carbonate diagenesis, ash alteration, fluid migration, and diffusive exchange with the underlying oceanic crust.

\section{Introduction}

The Costa Rica Seismogenesis Project (CRISP) was designed to understand the processes that control fault zone behavior during earthquake nucleation and rupture propagation at erosional subduction zones. The CRISP study area, located offshore the Osa Peninsula of Costa Rica, is part of the active and long-lived subduction erosion from Guatemala to Costa Rica (Ranero et al., 2000a, 2000b; Vannucchi et al., 2004). This area is characterized by low sediment supply, fast convergence rate, abundant plate interface seismicity, and change in subducting plate relief along 
strike (Expedition 334 Scientists, 2012a; see also the "Expedition 344 summary" chapter [Harris et al., 2013a]). Arcward of the trench, the lower slope consists of a 10-12 km wide frontal prism, where a modern sediment apron overlies older sediment that may have been deposited in a fore-arc basin setting (A. Sakaguchi, pers. comm., 2013). The first phase of the CRISP focuses on sampling sediment, fluid, and crustal rock because fluid and associated diagenetic reactions affect hydrological parameters (e.g., permeability and pore pressure) and may regulate the mechanical state of the plate interface at depth. To this aim, seven sites were drilled on this margin during Integrated Ocean Drilling Program (IODP) Expeditions 334 and 344, which targeted sites on the upper and incoming plates (Fig. F1).

Because the isotopic composition of strontium does not undergo biological fractionation (Mook, 2001), it has proven to be valuable in establishing fluid-rock reactions, sources, and fluid mixing (e.g., Teichert et al., 2005; Torres et al., 2004; Solomon et al., 2009; Joseph et al., 2012). Potential source materials that may alter a de facto seawater ${ }^{87} \mathrm{Sr} /{ }^{86} \mathrm{Sr}$ ratio of interstitial fluids are continental detritus $\left({ }^{87} \mathrm{Sr} /{ }^{86} \mathrm{Sr}=\right.$ $\sim 0.7119-0.7133)$, biogenic calcite $\left({ }^{87} \mathrm{Sr} /{ }^{86} \mathrm{Sr}=\right.$ $\sim 0.7075-0.7092)$, volcanic ash $\left({ }^{87} \mathrm{Sr} /{ }^{86} \mathrm{Sr}=\sim 0.706-\right.$ $0.704)$, and oceanic crust $\left({ }^{87} \mathrm{Sr} /{ }^{86} \mathrm{Sr}=\sim 0.703\right)$ (Veizer, $1989)$. Here we report on pore water strontium isotopic composition of subsamples collected from the seven sites drilled during Expeditions 334 and 344.

\section{Study sites}

Five sites were drilled on the overriding plate and sampled the upper and middle slope regions and the prism toe. Two additional sites were drilled in the incoming Cocos plate (Fig. F1). Complete descriptions of the drilling results are given in Expedition 334 Scientists (2012a) and in the "Expedition 344 summary" chapter (Harris et al., 2013a).

The shallowest site along the CRISP transect, Site U1379, was drilled into the upper slope of the Costa Rica margin, $34 \mathrm{~km}$ offshore the Osa Peninsula. This site is thought to overlie the locked portion of the subduction zone seismogenic zone in an area where the plate boundary is $4.5 \mathrm{~km}$ below seafloor. Sediment from Site U1379 is divided into five lithostratigraphic units (Fig. F2A).

Site U1378 was drilled into the middle slope of the Costa Rica margin, $41 \mathrm{~km}$ offshore the Osa Peninsula (Fig. F1). This site is located above the unlocked portion of the plate boundary, as indicated by interplate earthquake relocation and geodetic measurements (LaFemina et al., 2009). The margin here consists of an upper plate framework wedge underlying $\sim 550 \mathrm{~m}$ of slope sediment. Drilling at this site penetrated a landward-dipping reflector interpreted as a normal fault cutting through the whole upper plate, which may be directly linked with the plate boundary. The sediment at Site U1378 is dominantly composed of a monotonous sequence of silty clay to clay that alternates with widely interspersed centimeter-scale sandy layers, and was divided into three main lithostratigraphic units (Fig. F2).

Site U1380 is a complementary site to nearby Site U1378 where only the upper part ( 400 [meters below seafloor [mbsf]) of the slope sediment was drilled during Expedition 334. Site U1380 was drilled to investigate the deeper portions of the upper slope sequence and underlying wedge sediment. The site was cored between $~ 395$ and 480 mbsf during Expedition 334 but was abandoned before science goals were achieved because of hole instability. Hole U1380C was cored during Expedition 344. The sedimentary succession recovered from the framework wedge revealed an alternating terrestrially sourced, turbiditic upper slope (Units I and III) to shelf (Unit II) sequence, eventually being influenced by deltaic-derived sediment (Fig. F2).

Farther north, Site U1413 was also drilled in the middle slope region within a 3-D seismic volume collected in 2013 (Bangs et al., 2013). Three lithostratigraphic units (Fig. F3) can be distinguished in the sediment of Site U1413. The frontal sedimentary prism at the base of the slope was drilled at Site U1412 (Fig. F1). The primary goal of this site was to penetrate the décollement and investigate the fluid flow regime within the sediment as well as the oceanic crust. Three units were distinguished in the sedimentary rock (Fig. F3). Unfortunately, due to hole instability, the décollement and underthrust sediment were not sampled at Site U1412.

To understand seismogenic processes in convergent margins we need to fully characterize the sediment and oceanic crust entering the seismogenic zone. To this aim, two sites were drilled on the subducting aseismic Cocos Ridge. Incoming sediment thickness at Site U1414 is $380 \mathrm{~m}$, and a much thinner section $(<100 \mathrm{~m})$ was recovered at Site U1381 located higher on Cocos Ridge. The upper $50 \mathrm{~m}$ of Site U1381 is composed of a predominantly monotonous sequence of silty clay to clay (Unit I), which is underlain by a more pelagic sequence (Unit II) characterized by abundant biogenic components (Fig. F4). The contact between the basement and the overlying sediment was recovered at $~ 95$ mbsf in Hole U1381B and at 104 mbsf in Hole U1381C. 


\section{Analytical methods}

Pore fluid was collected from whole-round cores that were cut on the catwalk immediately after recovery, capped, and taken to the laboratory for processing using a titanium squeezer, modified after the stainless-steel squeezer of Manheim and Sayles (1974). Gauge pressures up to $30 \mathrm{MPa}$ were applied using a laboratory hydraulic press to extract pore water. Pore fluid was passed through a prewashed Whatman No. 1 filter fitted above a titanium screen, filtered through a $0.2 \mu \mathrm{m}$ Gelman polysulfone disposable filter, and subsequently extruded into a precleaned $(10 \% \mathrm{HCl}), 60 \mathrm{~mL}$ plastic syringe attached to the bottom of the squeezer assembly. Details of this procedure are given Expedition 334 Scientists (2012b) and in the "Methods" chapter (Harris et al., 2013d).

Strontium concentrations in pore fluids collected during Expedition 334 were measured postcruise by inductively coupled plasma-optical emission spectrometry (ICP-OES) at Oregon State University, as reported by Torres et al. (2014). During Expedition 344 , pore fluid Sr concentrations were measured on board by inductively coupled plasma-atomic emission spectroscopy (ICP-AES), and the data are reported in the "Expedition 344 summary" chapter (Harris et al., 2013a).

High-precision chloride concentrations were acquired on board during both Expeditions 334 and 344 using a Metrohm 785 DMP autotitrator and silver nitrate $\left(\mathrm{AgNO}_{3}\right)$. International Association for the Physical Sciences of the Oceans seawater was used as the standard (Expedition 334 Scientists, 2012b; see also the "Methods" chapter [Harris et al., 2013d]).

During Expedition 334, sulfate data were obtained using the shipboard ICP-AES, and the data are reported by Vannucchi, Ujiie, Stroncik, and the Expedition 334 Scientists (2012). During Expedition 344, sulfate concentrations were determined with a Metrohm 861.004 advanced compact ion chromatograph (IC). Details of the procedure and results are given in the "Methods" chapter (Harris et al., 2013d).

For analysis of the ${ }^{87} \mathrm{Sr} /{ }^{86} \mathrm{Sr}$ ratios, aliquots of acidified pore fluid samples containing 300 ng Sr were directly loaded onto chromatographic columns. Samples were collected in acid-washed Nalgene bottles and acidified with ultrapure $\mathrm{HNO}_{3}$ at a ratio of $20 \mu \mathrm{L}$ acid per milliliter of sample. Strontium separation was carried out using $50 \mu \mathrm{L}$ Sr-Spec resin from EICHROM. Isotopic analysis was performed using the NU multicollector inductively coupled plasma mass spectrometer (MC-ICPMS) housed in the W.M.
Keck Collaboratory for Plasma Spectrometry in the College of Earth, Ocean and Atmospheric Science at Oregon State University (USA). Instrument mass bias was corrected using an ${ }^{88} \mathrm{Sr} /{ }^{86} \mathrm{Sr}$ ratio of 8.375209 , and ${ }^{87} \mathrm{Sr} /{ }^{86} \mathrm{Sr}$ ratio data were normalized to the NBS 987 standard, with a reported ${ }^{87} \mathrm{Sr} /{ }^{86} \mathrm{Sr}$ ratio of 0.71025 , with an internal error of $\pm 0.00005\left(2 \sigma_{\text {mean }} ; n\right.$ $=91)$. Replicate analysis of an in house standard yielded a ${ }^{87} \mathrm{Sr} /{ }^{86} \mathrm{Sr}$ ratio of $0.70819 \pm 0.00006\left(2 \sigma_{\text {mean }}\right.$; $n=79$ ), representing our external error.

\section{Results and discussion}

A total of 187 pore fluid samples were analyzed, and the data are listed in Table T1. Figures F2, F3, and F4 show downhole $\mathrm{Sr}$ concentration and ${ }^{87} \mathrm{Sr} /{ }^{86} \mathrm{Sr}$ ratio depth profiles, in the context of the corresponding lithology and supporting pore fluid data.

\section{Overriding plate}

The upper sediment sections cored at all sites drilled on the upper plate show a significant decrease in the $\mathrm{Sr}$ isotopic ratios consistent with in situ alteration of tephra.

\section{Site U1379}

At Site U1379, ash alteration is more pronounced within the sediment of lithostratigraphic Subunit IIC and corresponds to an increase in strontium concentrations (Fig. F2). Release of nonradiogenic Sr during alteration of ash is well documented, and this reaction explains the decrease in $\mathrm{Sr}$ isotopic values at this site from a near-seawater ratio of 0.70908 to a minimum value of 0.70757 at 369 mbsf. The isotopic ratios within the remaining fluids of Unit II range from 0.70757 to 0.70829 . Unit III is dominated by coarser grained sediment as well as several fault zones below $\sim 600$ mbsf that host freshened fluids, as exhibited by the broad interval of low $\mathrm{Cl}$, which decreases sharply from $\sim 560$ mbsf and reaches its lowest concentration at $\sim 680$ mbsf (Expedition 334 Scientists, 2012c; Torres et al., 2013). Concomitant with the $\mathrm{Cl}$ decrease, dissolved $\mathrm{Sr}$ increases from $\sim 41 \mu \mathrm{M}$ at 560 mbsf to a broad maximum of $\sim 70 \mu \mathrm{M}$, in spite of the overall dilution trend evidenced in the Cl profile. In this zone, $\mathrm{Sr}$ isotopes have a less radiogenic component.

\section{Site U1378/U1380}

At Site U1378, drilled in the middle slope, $\mathrm{Cl}$ shows a more pronounced decrease relative to Site U1379. Site U1380 is a continuation of the sequence drilled at nearby Site U1378, and pore fluid data obtained 
here show discrete anomalies that mark the unconformity separating the slope apron from the underlying wedge material (Torres et al., 2013) (Fig. F2). The $\mathrm{Sr}$ isotopic data in fluid from Site U1378 show a steady decrease from seawater value, which points to alteration of tephra throughout Unit II. This process is more pronounced within the sediment interval from 360 to $425 \mathrm{mbsf}$, where ${ }^{87} \mathrm{Sr} /{ }^{86} \mathrm{Sr}$ ratios show a broad minimum ranging from 0.70802 to 0.70791 . Immediately below the zone displaying this broad minimum, ${ }^{87} \mathrm{Sr} /{ }^{86} \mathrm{Sr}$ ratios increase rapidly in samples collected just above the framework sediment, from 450 to $500 \mathrm{mbsf}$. The $\mathrm{Sr}$ isotopic composition in this zone ranges from 0.70834 to 0.70844 , values that are similar to those measured within the unconformity drilled at Site U1379. The Sr concentration within the unconformity at Site U1380 is lower than that measured at Site U1379, reflecting the larger degree of dilution by fluid freshening in the middle slope region. Below the unconformity, $\mathrm{Sr}$ isotopic values show a steady increase with depth to a value of 0.70868 (at $552 \mathrm{mbsf}$ ), accompanied by a general increase in dissolved Sr concentration.

\section{Site U1413}

At Site U1413, Ca and Mg concentrations decrease from seawater values at the seafloor to a minimum of 1.1 and $39.8 \mathrm{mM}$, respectively, at the Unit I/II boundary (see the "Upper slope Site U1413" chapter [Harris et al., 2013e]), possibly reflecting precipitation of authigenic carbonates, an observation that is consistent with the sharp decrease in dissolved $\mathrm{Sr}$ concentration in these shallow sequences (Fig. F3). Strontium, however, is not fractionated during carbonate precipitation, and therefore the observed steady decrease in ${ }^{87} \mathrm{Sr} /{ }^{86} \mathrm{Sr}$ ratios from a near-seawater value of 0.70916 in the shallowest sample analyzed (4.4 mbsf) to 0.70899 at $24.4 \mathrm{mbsf}$ indicates a component of ash alteration. Tephra were commonly observed in Unit I to a depth of $\sim 35$ mbsf. In Unit II, both the Sr concentration and its isotopic composition remain relatively constant in the depth interval from 24.4 to $135 \mathrm{mbsf}$, below which there is a marked decrease in ${ }^{87} \mathrm{Sr} /{ }^{86} \mathrm{Sr}$ ratio, which sharply declines from 0.70890 to 0.70824 at 178 mbsf. There is only a single, thin tephra layer reported in sediment from 40 to $140 \mathrm{mbsf}$, but increased occurrence was noted from 135 to 180 mbsf. These observations suggest that the alteration of reactive ash is controlling the Sr isotopic composition. Although not apparent in lithology, the $\mathrm{Cl}$ and $\mathrm{Sr}$ profiles display a different behavior below 200 mbsf. Cl shows a steady decrease, whereas $\mathrm{Sr}$ remains relatively constant. ${ }^{87} \mathrm{Sr} /{ }^{86} \mathrm{Sr}$ ratios also remain fairly constant to the bottom of the site at 578 mbsf.

\section{Site U1412}

At Site U1412, drilled on the prism toe, borehole instability precluded sampling the décollement and recovering the underthrust sediment and igneous basement. The geochemistry of pore fluids largely indicates in situ diagenetic reactions. Because of the poor sample coverage, we grouped the Sr isotope data into three regions, constrained by sample recovery. In the shallowest section, the Sr isotopic values steadily decrease with depth, from the near-seawater value of 0.70918 at $1.4 \mathrm{mbsf}$ to 0.70888 at $111 \mathrm{mbsf}$, likely reflecting volcanic ash alteration. Only three samples were analyzed between 176.4 and 196 mbsf, with values ranging from 0.70843 to 0.70856 , and correspond to the Unit I/II boundary. Only five samples were analyzed from the deepest sections, 328.8$369.02 \mathrm{mbsf}$, and these display the lowest measured values at this site, from 0.70887 to 0.70837 .

\section{Incoming plate}

\section{Site U1381}

Site U1381 was cored during both Expeditions 334 and 344 . The data collected during both expeditions show highly consistent values (Fig. F4). The shallowest sample (1.45 mbsf) analyzed at this site has an ${ }^{87} \mathrm{Sr} /{ }^{86} \mathrm{Sr}$ ratio of 0.70918 , which is within the uncertainty of the seawater value of 0.70917 . The geochemical profiles obtained shipboard at Site U1381 indicate that the deep sediment at this site are influenced by diffusional communication with a fluid in the igneous basement (Expedition 334 Scientists, 2012d; see also the "Input Site U1381" chapter [Harris et al., 2013c). Most characteristic of this effect are sulfate profiles that show a reversal to seawaterlike values at the bottom of the hole as observed here as well as in sites drilled offshore Nicoya during Ocean Drilling Program Legs 170 and 205 (Silver et al., 2000; Morris, Villinger, Klaus, et al., 2003). At Site U1381, Sr concentration increases with depth, concomitant with a decrease in the Sr isotopic values, corroborating the inference that the pore fluid within the upper basement has been modified by alteration of the basaltic crust.

\section{Site U1414}

The pore fluid composition in the uppermost $80 \mathrm{~m}$ of Site U1414 shows trends in alkalinity, sulfate, and ammonium characteristic of organic matter remineralization (see the "Input Site U1414" chapter [Harris et al., 2013b]). In addition, the alteration of ash layers commonly observed throughout the sediment sequence lead to the observed decrease in ${ }^{87} \mathrm{Sr} /{ }^{86} \mathrm{Sr}$ ratios, from 0.7091 measured in the shallowest sample analyzed (0.56 mbsf) to 0.70874 at $\sim 150 \mathrm{mbsf}$, at the 
lithostratigraphic Unit I/II boundary. The dissolved Sr concentration remains relatively constant within this interval, suggesting that the main reaction involving strontium in Unit I is ash alteration, and there is very little carbonate precipitation. The large increase in $\mathrm{Sr}$ concentrations within Unit II, which is dominated by nannofossil-rich calcareous ooze, is the result of carbonate recrystallization, as has been observed in other pelagic carbonate-rich sediment (e.g., Site 1039 off the Nicoya Peninsula of Costa Rica; Shipboard Scientific Party, 1997). At the Unit II/III boundary ( 300 mbsf) there is a sharp increase in $\mathrm{Sr}$ concentrations, with a maximum value of 941 $\mu \mathrm{M}$ at 327 mbsf ( 10 times seawater value), suggesting more intense diagenetic reactions. This concentration change coincides with a seismic reflector and the onset of carbonate cementation (see the "Input Site U1414" chapter [Harris et al., 2013b]). The lowermost $66 \mathrm{~m}$ of the sediment column at Site U1414 (Unit III) is characterized by a sequence of lithified, calcareous, and siliceous cemented silt- and sandstone that probably lost its biogenic components as a result of diagenetic recrystallization. Fluids in this deepest sediment display the largest changes in $\mathrm{Sr}$ concentration as well as in its isotopic composition, which decreases from 0.70884 at 308 mbsf to 0.70861 measured in the deepest sample analyzed at $\sim 337$ mbsf. Basement was contacted at $\sim 375$ mbsf, but the deepest sediment was too cemented to obtain pore fluid samples. The ${ }^{87} \mathrm{Sr} /{ }^{86} \mathrm{Sr}$ ratio in the deepest sample analyzed is less radiogenic than the one measured at Site U1381 (0.70860). Intense carbonate recrystallization of these deepest sediments results in Sr concentrations that are almost an order of magnitude higher than those measured at the base of Site U1381.

\section{Acknowledgments}

This research used samples and data provided by the Integrated Ocean Drilling Program (IODP), which is sponsored by the US National Science Foundation and participating countries and universities under management of IODP Management International, Inc. The outstanding efforts of the Siem Offshore officers and crew as well as the drilling personnel and the scientific parties of IODP Expedition 344 are greatly acknowledged here. Without their hard work and dedication none of these samples could have been recovered for analysis. We acknowledge Lisa Tedder for her assistance with the Sr isotopic measurements of samples from Expedition 334. This research was funded by USSP postcruise research awards T334B11 and T344A11 (Expeditions 334 and 344) to Marta Torres.

\section{References}

Bangs, N.L., McIntosh, K.D., Silver, E.A., Ranero, C.R., Kluesner, J.W., von Huene, R., Cavanaugh, S., Graf, S., Cameselle, A.L., Baracco, A.M., and Nuñez, E., 2011. Preliminary results of the CRISP 3D seismic experiment, offshore Costa Rica [presented at the 2011 American Geophysical Union Fall Meeting, San Francisco, CA, 5-9 December 2011]. (Abstract T21B-2341) http:// www.agu.org/meetings/fm11/waisfm11.html

Bangs, N.L., McIntosh, K.D., Silver, E.A., Kluesner, J., and Ranero, C.R., 2013. Structural controls on the hydrogeology of the Costa Rica subduction thrust NW of the Osa Peninisula [presented at the 2013 American Geophysical Union Fall Meeting, San Francisco, CA, 9-13 December 2013]. (Abstract T51I-01) http://abstractsearch.agu.org/meetings/2013/FM/T51I-01.html

Expedition 334 Scientists, 2012a. Expedition 334 summary. In Vannucchi, P., Ujiie, K., Stroncik, N., and the Expedition 334 Scientists, Proc. IODP, 334: Tokyo (Integrated Ocean Drilling Program Management International, Inc.). doi:10.2204/iodp.proc.334.101.2012

Expedition 334 Scientists, 2012b. Methods. In Vannucchi, P., Ujiie, K., Stroncik, N., and the Expedition 334 Scientists, Proc. IODP, 334: Tokyo (Integrated Ocean Drilling Program Management International, Inc.).

doi:10.2204/iodp.proc.334.102.2012

Expedition 334 Scientists, 2012c. Site U1380. In Vannucchi, P., Ujiie, K., Stroncik, N., and the Expedition 334 Scientists, Proc. IODP, 334: Tokyo (Integrated Ocean Drilling Program Management International, Inc.). doi:10.2204/iodp.proc.334.105.2012

Expedition 334 Scientists, 2012d. Site U1381. In Vannucchi, P., Ujiie, K., Stroncik, N., and the Expedition 334 Scientists, Proc. IODP, 334: Tokyo (Integrated Ocean Drilling Program Management International, Inc.). doi:10.2204/iodp.proc.334.106.2012

Harris, R.N., Sakaguchi, A., Petronotis, K., Baxter, A.T., Berg, R., Burkett, A., Charpentier, D., Choi, J., Diz Ferreiro, P., Hamahashi, M., Hashimoto, Y., Heydolph, K., Jovane, L., Kastner, M., Kurz, W., Kutterolf, S.O., Li, Y., Malinverno, A., Martin, K.M., Millan, C., Nascimento, D.B., Saito, S., Sandoval Gutierrez, M.I., Screaton, E.J., Smith-Duque, C.E., Solomon, E.A., Straub, S.M., Tanikawa, W., Torres, M.E., Uchimura, H., Vannucchi, P., Yamamoto, Y., Yan, Q., and Zhao, X., 2013a. Expedition 344 summary. In Harris, R.N., Sakaguchi, A., Petronotis, K., and the Expedition 344 Scientists, Proc. IODP, 344: College Station, TX (Integrated Ocean Drilling Program). doi:10.2204/iodp.proc.344.101.2013

Harris, R.N., Sakaguchi, A., Petronotis, K., Baxter, A.T., Berg, R., Burkett, A., Charpentier, D., Choi, J., Diz Ferreiro, P., Hamahashi, M., Hashimoto, Y., Heydolph, K., Jovane, L., Kastner, M., Kurz, W., Kutterolf, S.O., Li, Y., Malinverno, A., Martin, K.M., Millan, C., Nascimento, D.B., Saito, S., Sandoval Gutierrez, M.I., Screaton, E.J., Smith-Duque, C.E., Solomon, E.A., Straub, S.M., Tanikawa, W., Torres, M.E., Uchimura, H., Vannucchi, P., Yamamoto, Y., Yan, Q., and Zhao, X., 2013b. Input Site 
U1414. In Harris, R.N., Sakaguchi, A., Petronotis, K., and the Expedition 344 Scientists, Proc. IODP, 344: College Station, TX (Integrated Ocean Drilling Program). doi:10.2204/iodp.proc.344.104.2013

Harris, R.N., Sakaguchi, A., Petronotis, K., Baxter, A.T., Berg, R., Burkett, A., Charpentier, D., Choi, J., Diz Ferreiro, P., Hamahashi, M., Hashimoto, Y., Heydolph, K., Jovane, L., Kastner, M., Kurz, W., Kutterolf, S.O., Li, Y., Malinverno, A., Martin, K.M., Millan, C., Nascimento, D.B., Saito, S., Sandoval Gutierrez, M.I., Screaton, E.J., Smith-Duque, C.E., Solomon, E.A., Straub, S.M., Tanikawa, W., Torres, M.E., Uchimura, H., Vannucchi, P., Yamamoto, Y., Yan, Q., and Zhao, X., 2013c. Input Site U1381. In Harris, R.N., Sakaguchi, A., Petronotis, K., and the Expedition 344 Scientists, Proc. IODP, 344: College Station, TX (Integrated Ocean Drilling Program). doi:10.2204/iodp.proc.344.103.2013

Harris, R.N., Sakaguchi, A., Petronotis, K., Baxter, A.T., Berg, R., Burkett, A., Charpentier, D., Choi, J., Diz Ferreiro, P., Hamahashi, M., Hashimoto, Y., Heydolph, K., Jovane, L., Kastner, M., Kurz, W., Kutterolf, S.O., Li, Y., Malinverno, A., Martin, K.M., Millan, C., Nascimento, D.B., Saito, S., Sandoval Gutierrez, M.I., Screaton, E.J., Smith-Duque, C.E., Solomon, E.A., Straub, S.M., Tanikawa, W., Torres, M.E., Uchimura, H., Vannucchi, P., Yamamoto, Y., Yan, Q., and Zhao, X., 2013d. Methods. In Harris, R.N., Sakaguchi, A., Petronotis, K., and the Expedition 344 Scientists, Proc. IODP, 344: College Station, TX (Integrated Ocean Drilling Program). doi:10.2204/iodp.proc.344.102.2013

Harris, R.N., Sakaguchi, A., Petronotis, K., Baxter, A.T., Berg, R., Burkett, A., Charpentier, D., Choi, J., Diz Ferreiro, P., Hamahashi, M., Hashimoto, Y., Heydolph, K., Jovane, L., Kastner, M., Kurz, W., Kutterolf, S.O., Li, Y., Malinverno, A., Martin, K.M., Millan, C., Nascimento, D.B., Saito, S., Sandoval Gutierrez, M.I., Screaton, E.J., Smith-Duque, C.E., Solomon, E.A., Straub, S.M., Tanikawa, W., Torres, M.E., Uchimura, H., Vannucchi, P., Yamamoto, Y., Yan, Q., and Zhao, X., 2013e. Upper slope Site U1413. In Harris, R.N., Sakaguchi, A., Petronotis, K., and the Expedition 344 Scientists, Proc. IODP, 344: College Station, TX (Integrated Ocean Drilling Program). doi:10.2204/iodp.proc.344.107.2013

Joseph, C., Torres, M.E., Martin, R.A., Haley, B.A., Pohlman, J.W., Riedel, M., and Rose, K., 2012. Using the ${ }^{87} \mathrm{Sr} /$ ${ }^{86} \mathrm{Sr}$ of modern and paleoseep carbonates from northern Cascadia to link modern fluid flow to the past. Chem. Geol., 334:122-130. doi:10.1016/j.chem-

geo.2012.10.020

LaFemina, P., Dixon, T.H., Govers, R., Norabuena, E., Turner, H., Saballos, A., Mattioli, G., Protti, M., and Strauch, W., 2009. Fore-arc motion and Cocos Ridge collision in Central America. Geochem., Geophys., Geosyst., 10(5):Q05S14. doi:10.1029/2008GC002181

Manheim, F.T., and Sayles, F.L., 1974. Composition and origin of interstitial waters of marine sediments, based on deep sea drill cores. In Goldberg, E.D. (Ed.), The Sea (Vol. 5): Marine Chemistry: The Sedimentary Cycle: New York (Wiley), 527-568.
Mook, W.G., 2001. Application to low temperature systems. In Geyh, M. (Ed.), Environmental Isotopes in the Hydrological Cycle: Principles and Applications (Vol. 4): Groundwater: Saturated and Unsaturated Zone: Vienna (Int. At. Energy Agency), 49-118. http://wwwnaweb.iaea.org/napc/ih/documents/global_cycle/ vol\%20IV/IV_Ch5.pdf

Morris, J.D., Villinger, H.W., Klaus, A., et al., 2003. Proc. ODP, Init. Repts., 205: College Station, TX (Ocean Drilling Program). doi:10.2973/odp.proc.ir.205.2003

Ranero, C.R., and von Huene, R., 2000a. Subduction erosion along the Middle America convergent margin. Nature, 404(6779):748-752. doi:10.1038/35008046

Ranero, C.R., von Huene, R., Flueh, E., Duarte, M., Baca, D., and McIntosh, K., 2000b. A cross section of the convergent Pacific margin of Nicaragua. Tectonics, 19(2):335-357. doi:10.1029/1999TC900045

Shipboard Scientific Party, 1997. Site 1039. In Kimura, G., Silver, E., Blum, P., et al., Proc. ODP, Init.Repts., 170: College Station, TX (Ocean Drilling Program), 45-93. doi:10.2973/odp.proc.ir.170.103.1997

Silver, E., Fisher, A., Saffer, D., Kastner, M., Morris, J., and McIntosh, K., 2000. Fluid flow paths in the Middle America Trench and Costa Rica margin. Geology, 28(8):679-682. doi:10.1130/00917613(2000)28<679:FFPITM>2.0.CO;2

Solomon, E.A., Kastner, M., Wheat, C.G., Jannasch, H., Robertson, G., Davis, E.E., and Morris, J.D., 2009. Longterm hydrogeochemical records in the oceanic basement and forearc prism at the Costa Rica subduction zone. Earth Planet. Sci. Lett., 282(1-4):240-251. doi:10.1016/j.epsl.2009.03.022

Teichert, B.M.A., Torres, M.E., Bohrmann, G., and Eisenhauer, A., 2005. Fluid sources, fluid pathways and diagenetic reactions across an accretionary prism revealed by Sr and B geochemistry. Earth Planet. Sci. Lett., 239(12):106-121. doi:10.1016/j.epsl.2005.08.002

Torres, M.E., Solomon, E.A., Kastner, M., Harris, R.N., Formolo, M., Choi, J., Berg, R.D., and Nuzzo, M., 2013. Geochemical evidence for fluid flow in the upper and subducting plates of the Costa Rica margin: results from CRISP drilling during Exp. 334 and 344 [presented at the 2013 American Geophysical Union Fall Meeting, San Francisco, CA, 9-13 December 2013]. (Abstract T34C-02) http://abstractsearch.agu.org/meetings/ 2013/FM/sections/T/sessions/T34C/abstracts/T34C02.html

Torres, M.E., Muratli, J.M., and Solomon, E.A., 2014. Data report: minor element concentrations in pore fluids from the CRISP-A transect drilled during Expedition 334. In Vannucchi, P., Ujiie, K., Stroncik, N., Malinverno, A., and the Expedition 334 Scientists, Proc. IODP, 334: Tokyo (Integrated Ocean Drilling Program Management International, Inc.). doi:10.2204/ iodp.proc.334.105.2014

Torres, M.E., Teichert, B.M.A., Tréhu, A.M., Borowski, W., and Tomaru, H., 2004. Relationship of pore water freshening to accretionary processes in the Cascadia margin: 
fluid sources and gas hydrate abundance. Geophys. Res. Lett., 31(22):L22305. doi:10.1029/2004GL021219

Vannucchi, P., Galeotti, S., Clift, P.D., Ranero, C.R., and von Huene, R., 2004. Long-term subduction-erosion along the Guatemalan margin of the Middle America Trench. Geology, 32(7):617-620. doi:10.1130/G20422.1

Vannucchi, P., Ujiie, K., Stroncik, N., and the Expedition 334 Scientists, 2012. Proc. IODP, 334: Tokyo (Integrated Ocean Drilling Program Management International, Inc.). doi:10.2204/iodp.proc.334.2012
Veizer, J., 1989. Strontium isotopes in seawater through time. Annu. Rev. Earth Planet. Sci., 17(1):141-167. doi:10.1146/annurev.ea.17.050189.001041

Initial receipt: 4 March 2014

Acceptance: 17 February 2015

Publication: 18 May 2015

MS 344-201 
Figure F1. A. Location map of sites drilled during IODP CRISP program. B. Location of Sites U1378-U1381 drilled during Expedition 334 along the A- $\mathrm{A}^{\prime}$ transect from the incoming plate to the upper slope. During Expedition 344, new holes were drilled at Sites U1380 and U1381, as well as at Sites U1412-U1414. C. Schematic transect showing locations of sites along the A-A' transect and indicating projected locations for Sites U1413 and U1414 (Vannucchi, Ujiie, Stroncik, and the Expedition 334 Scientists, 2012; see also the "Expedition 344 summary" chapter [Harris et al., 2013a]).

A

B
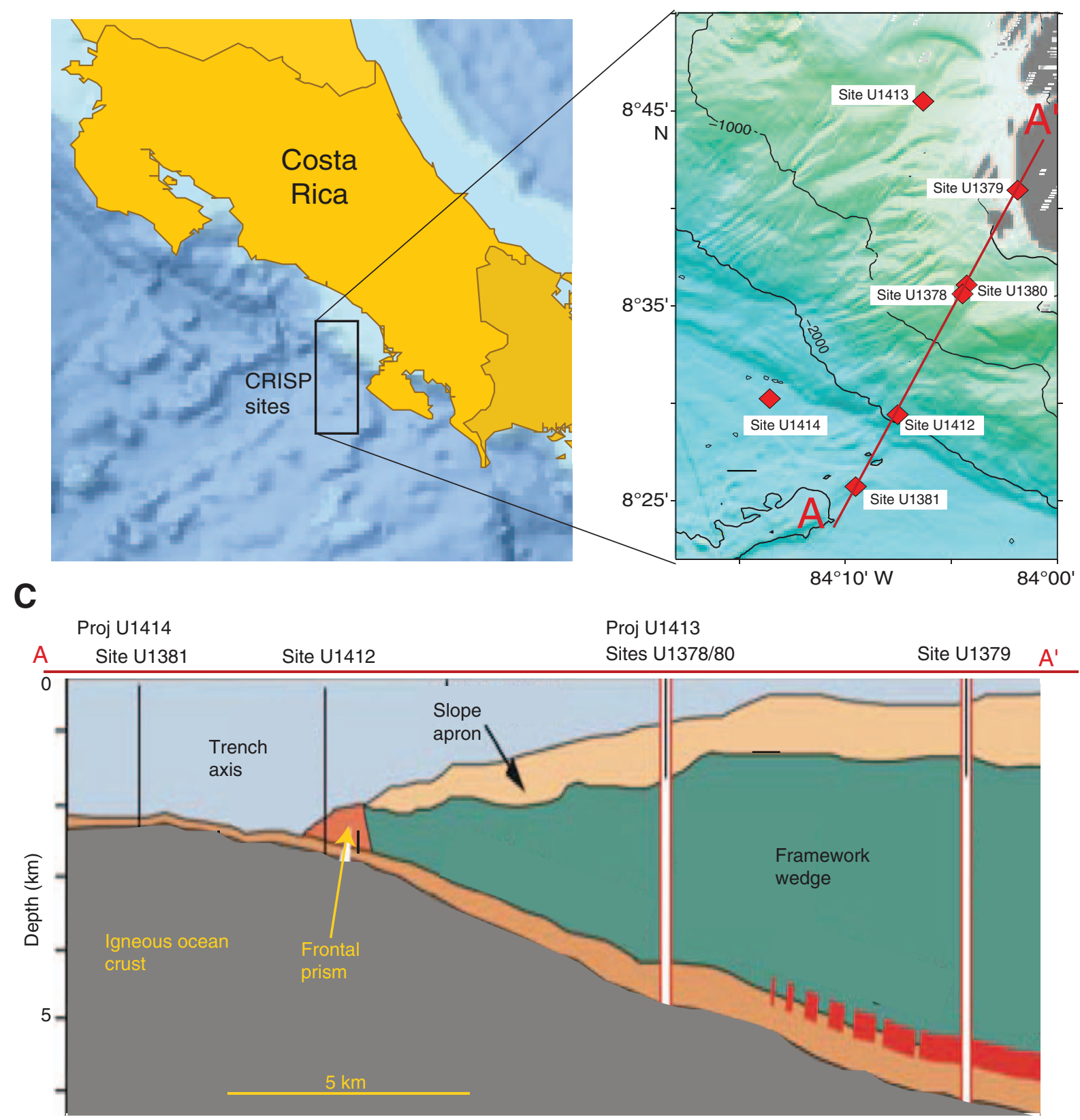
Figure F2. Downcore profiles for ${ }^{87} \mathrm{Sr} /{ }^{86} \mathrm{Sr}$, Sr, and $\mathrm{Cl}$ in pore fluids from (A) Site U1379 (in the upper slope) and (B) Site U1378/U1380 drilled in the middle slope. Lithostratigraphic units are from Vannucchi, Ujiie, Stroncik, and the Expedition 334 Scientists (2012) and the "Expedition 344 summary" chapter (Harris et al., 2013a). Blue circles $=$ samples collected during Expedition 334, red circles $=$ samples from Expedition 344. Blue arrows $=$ seawater values, yellow zone $=$ a highly fractured horizon that marks the unconformity between the upper slope and framework rock at Sites U1378/U1380.

A

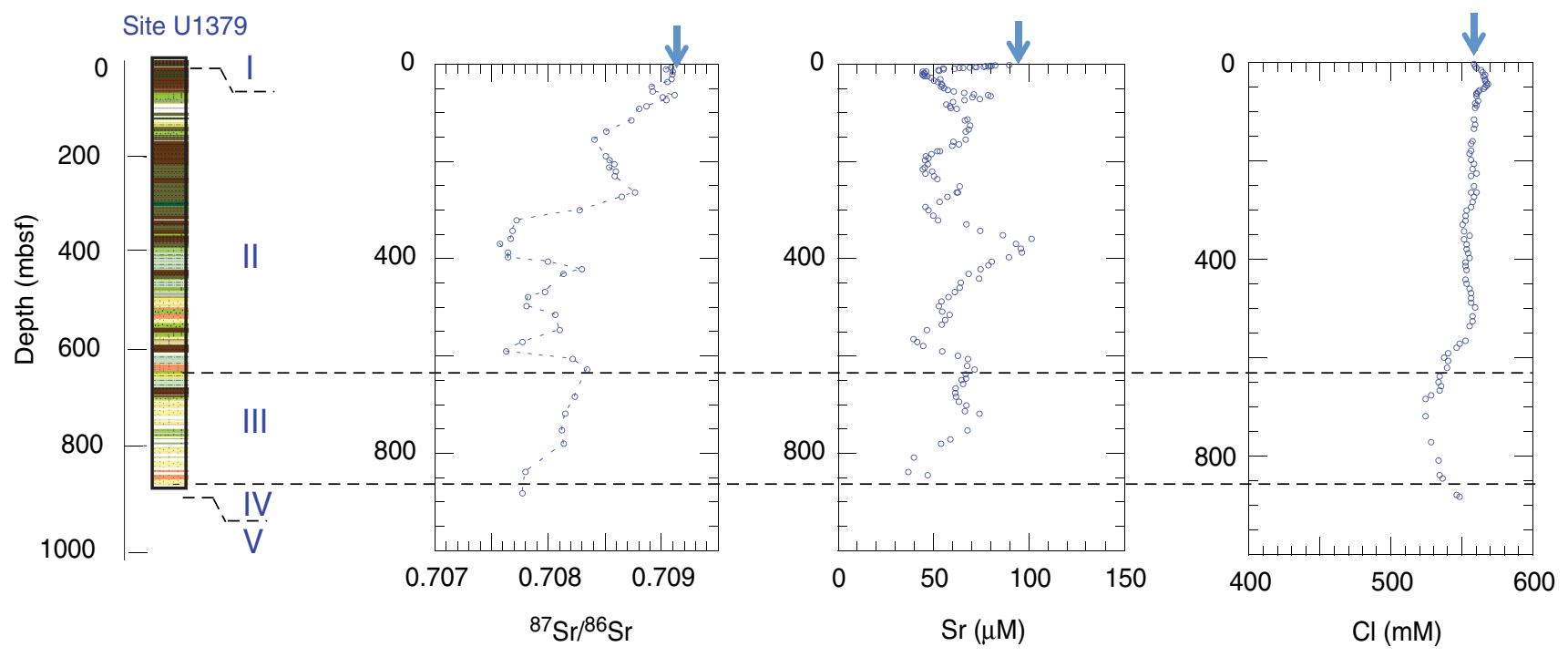

B

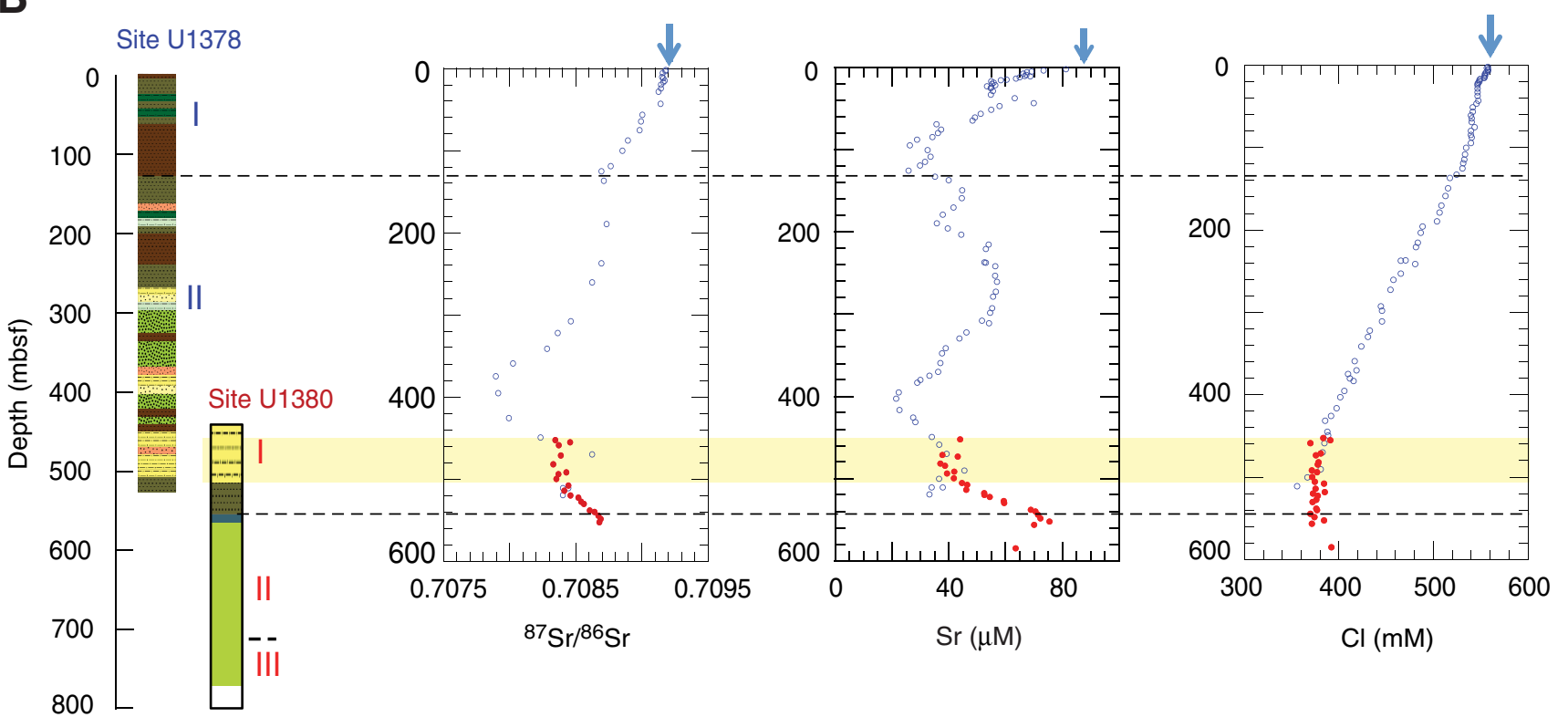


Figure F3. Downcore profiles for ${ }^{87} \mathrm{Sr} /{ }^{86} \mathrm{Sr}, \mathrm{Sr}$, and $\mathrm{Cl}$ in pore fluids from Sites U1412 (at the prism toe) and U1413 (middle slope). Lithostratigraphic units are from the "Expedition 344 summary" chapter (Harris et al., 2013a). Blue arrows = seawater values.
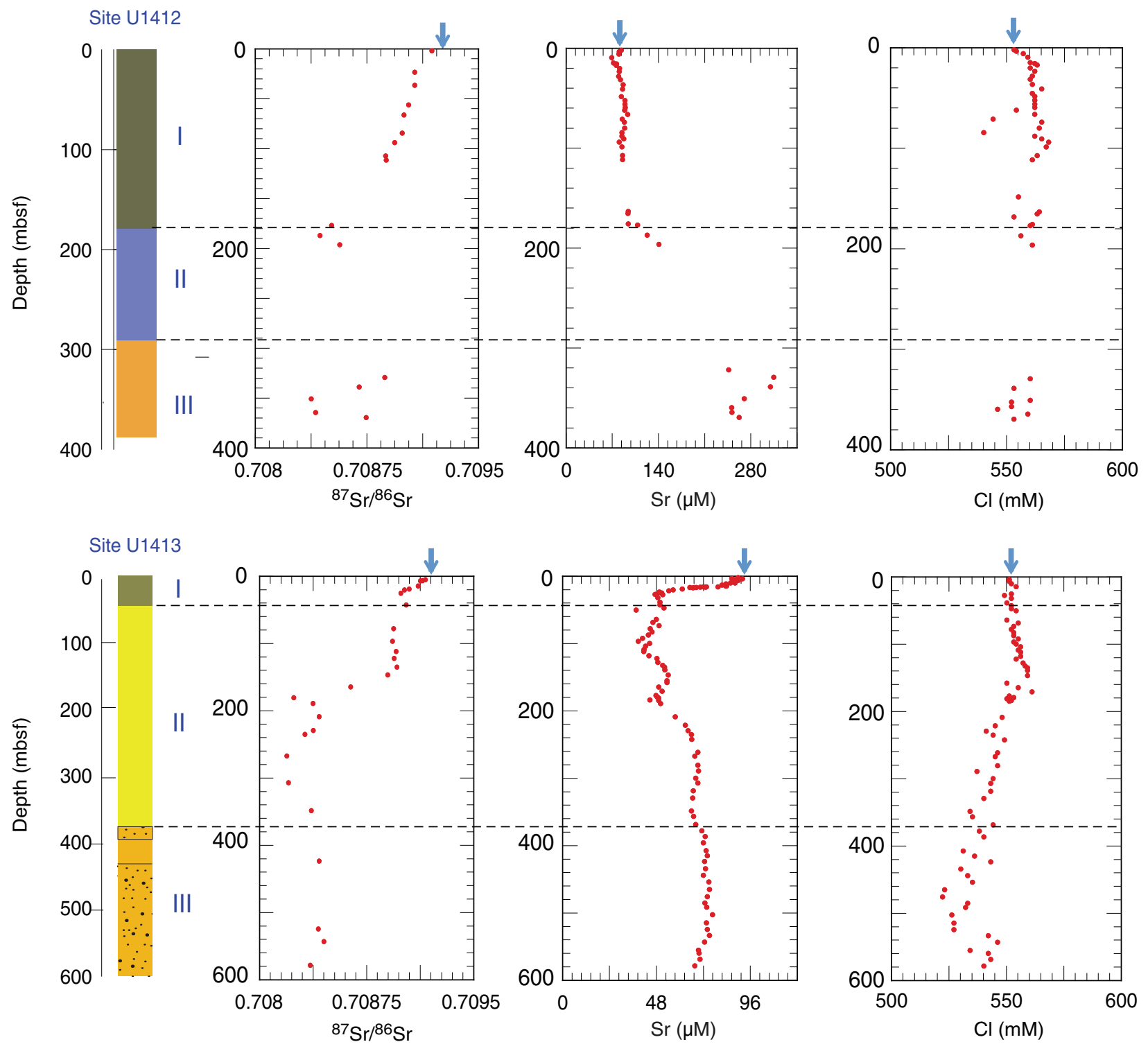
Figure F4. Downcore profiles for ${ }^{87} \mathrm{Sr} /{ }^{86} \mathrm{Sr}, \mathrm{Sr}$, and $\mathrm{SO}_{4}$ in pore fluids from Sites U1381 and U1414, drilled in the incoming Cocos plate. Lithostratigraphic units are from Vannucchi, Ujiie, Stroncik, and the Expedition 334 Scientists (2012) and the "Expedition 344 summary" chapter (Harris et al., 2013a). Blue circles = samples collected during Expedition 334, red circles = samples from Expedition 344. Blue arrows = seawater values.
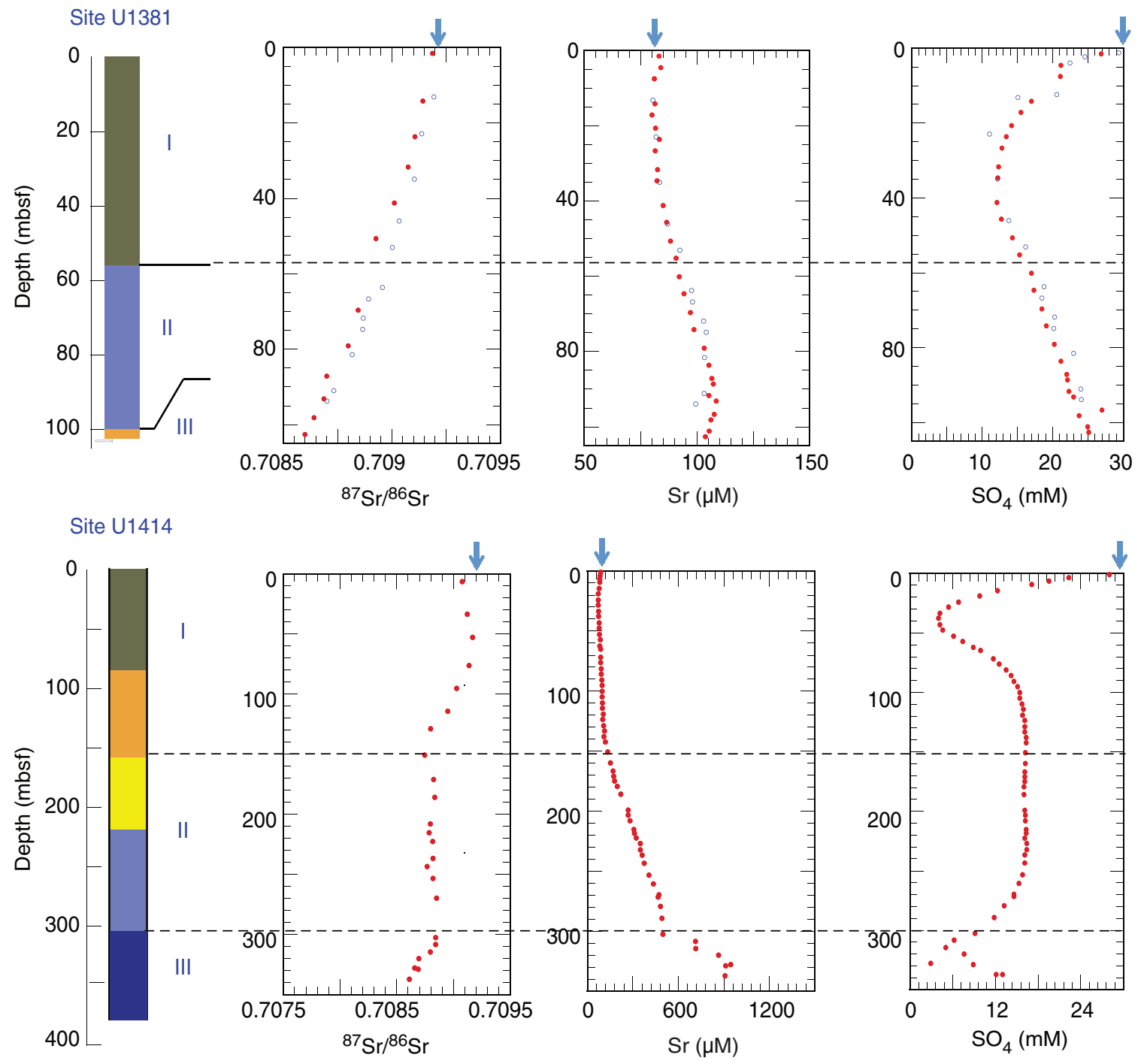
Table T1. Strontium concentrations and ${ }^{87} \mathrm{Sr} /{ }^{86} \mathrm{~S}$ ratios in pore fluid, Expeditions 334 and 344. (Continued on next page).

\begin{tabular}{|c|c|c|c|}
\hline $\begin{array}{l}\text { Core, section, } \\
\text { interval }(\mathrm{cm})\end{array}$ & $\begin{array}{l}\text { Depth } \\
\text { (mbsf) }\end{array}$ & $\begin{array}{c}\mathrm{Sr} \\
(\mu \mathrm{M})\end{array}$ & ${ }^{87} \mathrm{Sr} /{ }^{86} \mathrm{Sr}$ \\
\hline \multicolumn{4}{|l|}{ 334-U1378B- } \\
\hline $1 \mathrm{H}-1,138-150$ & 1.4 & 81.1 & 0.70918 \\
\hline $1 \mathrm{H}-2,138-150$ & 2.9 & 73.2 & 0.70917 \\
\hline $1 \mathrm{H}-4,46-58$ & 5.0 & 67.3 & 0.70916 \\
\hline $2 \mathrm{H}-3,138-150$ & 9.7 & 66.5 & 0.70915 \\
\hline $2 \mathrm{H}-4,138-150$ & 11.2 & 64.9 & 0.70916 \\
\hline $2 \mathrm{H}-6,138-150$ & 14.2 & 60.2 & 0.70917 \\
\hline $3 \mathrm{H}-1,138-150$ & 16.2 & 54.8 & 0.70916 \\
\hline $3 \mathrm{H}-3,138-150$ & 19.2 & 55.0 & 0.70914 \\
\hline $3 \mathrm{H}-6,1$ & 23.7 & 54.8 & 0.70914 \\
\hline $4 \mathrm{H}-3,138-150$ & 27.9 & 55.3 & 0.70912 \\
\hline $5 \mathrm{H}-6,138-150$ & 42.7 & 69.8 & 0.70914 \\
\hline 7H-2, 138-150 & 55.7 & 51.1 & 0.70900 \\
\hline $8 \mathrm{H}-2,1$ & 63.9 & 48.2 & \\
\hline $9 \mathrm{H}-2,13$ & 74.7 & 37.1 & 0898 \\
\hline $10 \mathrm{H}-4,138$ & 87.2 & 28.7 & 889 \\
\hline $12 \mathrm{H}-3,138-150$ & 99.9 & 32.4 & 0.70885 \\
\hline $15 \mathrm{H}-2,1$ & 118.5 & 29.7 & 0.70876 \\
\hline $16 \mathrm{H}-3,1$ & 124.8 & 25.7 & 0.70869 \\
\hline $18 X-3,1$ & 136.4 & 39.8 & 0.70871 \\
\hline $23 X-6,1$ & 188.9 & & \\
\hline $29 X-3,4$ & 236.9 & 52.9 & 0.70869 \\
\hline & 260.0 & 56.7 & \\
\hline $37 X-2,9$ & 307.4 & 51.5 & 0.70846 \\
\hline $39 X-5,1$ & 321.8 & 46.0 & 0.70836 \\
\hline $41 X-5,1$ & 340.9 & 38.7 & 0.70828 \\
\hline $43 X-5,5$ & 358.9 & 36.9 & 0.70802 \\
\hline $46 \mathrm{X}-2$ & 374.4 & 3.1 & \\
\hline $49 X-$ & 394.8 & 22.2 & 791 \\
\hline $52 X-$ & 2 & & \\
\hline $55 X-2,81-117$ & 449.0 & 33.9 & 0.70823 \\
\hline $57 X-3,6$ & 469.5 & 39.1 & \\
\hline $61 x$ & 10.3 & 33.8 & 0.7 \\
\hline $62 x$ & 0.4 & 7.7 & 840 \\
\hline $63 X-4,8$ & & & \\
\hline \multicolumn{4}{|l|}{ 334-U1379C- } \\
\hline & 6.0 & 70.4 & 0.70908 \\
\hline & 97 & 56.8 & \\
\hline & 4.2 & 47.6 & 909 \\
\hline $3 \mathrm{H}$ & 0.6 & 45.6 & 909 \\
\hline $4 \mathrm{H}-4,92-92$ & 29.7 & 54.9 & 0.70908 \\
\hline $5 \mathrm{H}-4,149-14$ & 36.2 & 53.6 & 0.70905 \\
\hline & & & \\
\hline $8 \mathrm{H}$ & 55.0 & 1.8 & 392 \\
\hline $10 \mathrm{H}-1,8$ & 62.4 & 79.8 & 0911 \\
\hline $11 \mathrm{H}-3,78-78$ & 67.3 & 71.7 & 0.70901 \\
\hline $12 \mathrm{H}-4,1$ & 73.3 & 67.7 & 0.70904 \\
\hline & 86.2 & 59.9 & 0.70886 \\
\hline $17 \mathrm{H}-1,76-76$ & 1.0 & 63.5 & 880 \\
\hline , 137-1 & 1 & 67.9 & 0873 \\
\hline & 138.1 & 68.1 & 0.70851 \\
\hline & & 68.2 & \\
\hline 27 & 188.0 & 47.3 & 0.70850 \\
\hline $28 X-6,1$ & 196.8 & 47.0 & 0.70854 \\
\hline $29 X-4,120-137$ & 204.6 & 48.3 & 0.70858 \\
\hline $30 \times-2,133-133$ & 211.6 & 46.7 & 0.70853 \\
\hline & 2194 & 50.6 & \\
\hline $32 X-2,1$ & 200 & 515 & 0.70858 \\
\hline & 2 & 64.1 & 0876 \\
\hline $36 \mathrm{X}-5,128-128$ & 271.8 & 58.6 & 0.70865 \\
\hline $39 X-3,129-129$ & 299.3 & 48.7 & 0.70827 \\
\hline & & 53.7 & \\
\hline & 2 & 75.8 & \\
\hline $45 X-4,118-140$ & 358.5 & 103 & 0.70767 \\
\hline $46 X-5,75-100$ & 368.6 & 94.6 & 0.70757 \\
\hline & 386.4 & 97.6 & 0.70764 \\
\hline $49 \times-6,75-100$ & 396.0 & 90.9 & 0.70764 \\
\hline
\end{tabular}

\begin{tabular}{|c|c|c|c|}
\hline $\begin{array}{l}\text { Core, section, } \\
\text { interval }(\mathrm{cm})\end{array}$ & $\begin{array}{l}\text { Depth } \\
\text { (mbsf) }\end{array}$ & $\begin{array}{c}\mathrm{Sr} \\
(\mu \mathrm{M})\end{array}$ & ${ }^{87} \mathrm{Sr} /{ }^{86} \mathrm{Sr}$ \\
\hline $50 X-5,104-132$ & 405.3 & 81.8 & 0.70799 \\
\hline $52 X-2,118-118$ & 420.2 & 76.0 & 0.70829 \\
\hline $53 X-3,118-118$ & 430.5 & 69.7 & 0.70813 \\
\hline $57 X-3,118-150$ & 467.7 & 62.6 & 0.70797 \\
\hline $58 X-4,90-90$ & 477.7 & 59.2 & 0.70782 \\
\hline $60 X-4,118-150$ & 496.5 & 54.1 & 0.70781 \\
\hline $62 X-4,68-100$ & 514.6 & 59.8 & 0.70806 \\
\hline $65 X-6,78-114$ & 545.3 & 47.9 & 0.70810 \\
\hline $68 X-4,88-120$ & 570.5 & 42.9 & 0.70777 \\
\hline $70 X-4,92-92$ & 589.9 & 55.9 & 0.70762 \\
\hline $72 X-2,88-120$ & 605.4 & 69.4 & 0.70821 \\
\hline $74 X-4,74-107$ & 626.5 & 72.9 & 0.70834 \\
\hline $81 X-2,100-132$ & 682.2 & 63.1 & 0.70823 \\
\hline $85 X-1,77-112$ & 717.3 & 75.4 & 0.70815 \\
\hline $89 \times-2,0-40$ & 751.8 & 69.2 & 0.70812 \\
\hline $92 X-3,94-131$ & 779.1 & 55.3 & 0.70813 \\
\hline $98 X-4,79-115$ & 837.4 & 38.1 & 0.70779 \\
\hline $103 X-2,34-60$ & 881.4 & & 0.70777 \\
\hline \multicolumn{4}{|l|}{ 344-U1380C- } \\
\hline $3 R-3,114-144$ & 451.9 & 43.8 & 0.70834 \\
\hline $3 R-5,112-142$ & 454.7 & - & 0.70846 \\
\hline $4 \mathrm{R}-1,51-81$ & 458.1 & - & 0.70836 \\
\hline $5 R-3,107-137$ & 470.7 & 37.6 & 0.70838 \\
\hline $6 R-3,122-153$ & 481.3 & 36.9 & 0.70833 \\
\hline $7 R-3,120-150$ & 491.0 & 41.8 & 0.70842 \\
\hline 7R-5, 87-107 & 493.4 & 39.2 & 0.70837 \\
\hline $8 R-2,116-146$ & 499.1 & 41.6 & 0.70835 \\
\hline 9R-1, 102-132 & 507.2 & 46.3 & 0.70844 \\
\hline 9R-6, 79-109 & 513.3 & 46.0 & 0.70841 \\
\hline 10R-4, 53-78 & 519.5 & 52.4 & 0.70846 \\
\hline $10 R-6,64-90$ & 521.9 & 54.3 & 0.70851 \\
\hline $11 \mathrm{R}-2,59-89$ & 526.9 & 59.2 & 0.70854 \\
\hline $11 R-4,87-117$ & 529.5 & 59.3 & 0.70856 \\
\hline $12 \mathrm{R}-2,79-113$ & 537.6 & 68.7 & 0.70860 \\
\hline $12 R-4,78-108$ & 539.6 & 70.3 & 0.70864 \\
\hline $12 \mathrm{R}-8,62-92$ & 543.7 & 71.2 & 0.70867 \\
\hline $13 R-3,50-80$ & 548.0 & 72.1 & 0.70868 \\
\hline $13 R-6,58-88$ & 551.9 & 75.3 & 0.70868 \\
\hline \multicolumn{4}{|l|}{ 334-U1381A- } \\
\hline $3 R-1,61-71$ & 13.1 & 80.2 & 0.70919 \\
\hline $4 R-1,46-56$ & 22.8 & 81.7 & 0.70914 \\
\hline $5 R-2,135-150$ & 34.8 & 83.2 & 0.70910 \\
\hline $6 R-3,135-150$ & 45.9 & 86.8 & 0.70903 \\
\hline 7R-2, 60-75 & 52.9 & 92.3 & 0.70900 \\
\hline $8 R-2,135-15$ & 63.6 & 97.5 & 0.70895 \\
\hline $8 R-4,135-150$ & 66.6 & 97.9 & 0.70889 \\
\hline $9 R-1,135-150$ & 71.8 & 103 & 0.70887 \\
\hline $9 R-3,135-150$ & 74.8 & 104 & 0.70886 \\
\hline 10R-1, 145-158 & 81.4 & 103 & 0.70882 \\
\hline $11 \mathrm{R}-1,135-150$ & 90.9 & 103 & 0.70873 \\
\hline $11 \mathrm{R}-3,120-135$ & 93.8 & 99.2 & 0.70870 \\
\hline \multicolumn{4}{|l|}{ 344-U1381C- } \\
\hline $1 \mathrm{H}-1,140-1$ & 1.5 & 83.0 & 0.70919 \\
\hline $2 \mathrm{H}-4,140-150$ & 14.1 & 81.2 & 0.70914 \\
\hline $3 \mathrm{H}-4,140-150$ & 23.6 & 83.1 & 0.70910 \\
\hline $4 \mathrm{H}-3,140-150$ & 31.6 & 82.3 & 0.70907 \\
\hline $5 \mathrm{H}-3,140-150$ & 41.1 & 84.8 & 0.70901 \\
\hline $6 \mathrm{H}-3,135-150$ & 50.6 & 88.0 & 0.70892 \\
\hline $7 \mathrm{H}-3,135-150$ & 60.0 & 92.0 & 0.70862 \\
\hline $8 \mathrm{H}-3,136-157$ & 69.6 & 96.9 & 0.70884 \\
\hline $9 \mathrm{H}-3,135-150$ & 79.0 & 103 & 0.70880 \\
\hline $10 \mathrm{H}-2,140-150$ & 87.1 & 106 & 0.70870 \\
\hline $10 \mathrm{H}-6,140-150$ & 93.1 & 108 & 0.70868 \\
\hline $11 \mathrm{H}-3,140-150$ & 98.1 & 106 & 0.70864 \\
\hline $11 \mathrm{H}-6,140-150$ & 102.6 & 104 & 0.70860 \\
\hline
\end{tabular}


Table T1 (continued).

\begin{tabular}{|c|c|c|c|}
\hline $\begin{array}{l}\text { Core, section, } \\
\text { interval }(\mathrm{cm})\end{array}$ & $\begin{array}{l}\text { Depth } \\
\text { (mbsf) }\end{array}$ & $\begin{array}{c}\mathrm{Sr} \\
(\mu \mathrm{M})\end{array}$ & ${ }^{87} \mathrm{Sr} /{ }^{86} \mathrm{Sr}$ \\
\hline \multicolumn{4}{|l|}{ 344-U1412A- } \\
\hline $1 \mathrm{H}-1,138-150$ & 1.4 & 82.9 & 0.70918 \\
\hline $3 \mathrm{H}-5,138-150$ & 22.8 & 79.9 & 0.70907 \\
\hline $5 \mathrm{H}-3,118-135$ & 36.2 & 85.7 & 0.70907 \\
\hline $7 \mathrm{H}-5,103-120$ & 55.9 & 88.3 & 0.70903 \\
\hline $9 \mathrm{H}-2,128-150$ & 65.8 & 92.7 & 0.70900 \\
\hline $11 \mathrm{H}-2,130-152$ & 83.9 & 83.7 & 0.70898 \\
\hline $13 \mathrm{H}-2,124-146$ & 93.6 & 79.7 & 0.70893 \\
\hline $15 \mathrm{H}-2,93-115$ & 106.8 & 85.1 & 0.70887 \\
\hline $16 X-2,126-148$ & 111.0 & 85.1 & 0.70888 \\
\hline \multicolumn{4}{|l|}{ 344-U1412B- } \\
\hline $5 X-1,120-140$ & 176.4 & 108 & 0.70851 \\
\hline $6 X-2,99-125$ & 186.7 & 122 & 0.70843 \\
\hline $7 X-2,51-73$ & 196.0 & 140 & 0.70856 \\
\hline \multicolumn{4}{|l|}{ 344-U1412C- } \\
\hline $5 R-1,0-36$ & 328.8 & 314 & 0.70887 \\
\hline $6 \mathrm{R}-1,9-20$ & 338.6 & 309 & 0.70870 \\
\hline 7R-2, 96-112 & 350.3 & 270 & 0.70837 \\
\hline $8 R-5,59-95$ & 364.1 & 251 & 0.70840 \\
\hline $9 R-2,58-88$ & 369.0 & 262 & 0.70874 \\
\hline \multicolumn{4}{|l|}{ 344-U1413A- } \\
\hline $1 \mathrm{H}-4,110-122$ & 5.6 & 88.0 & 0.70914 \\
\hline $2 \mathrm{H}-5,138-150$ & 14.0 & 83.2 & 0.70911 \\
\hline $3 \mathrm{H}-6,140-152$ & 24.4 & 50.5 & 0.70899 \\
\hline $5 \mathrm{H}-5,135-150$ & 42.2 & 49.5 & 0.70902 \\
\hline $9 \mathrm{H}-5,135-155$ & 77.2 & 44.6 & 0.70893 \\
\hline $11 \mathrm{H}-5,130-152$ & 96.1 & 38.5 & 0.70893 \\
\hline $13 \mathrm{H}-4,130-152$ & 111.3 & 41.2 & 0.70895 \\
\hline $15 \mathrm{H}-2,130-152$ & 121.4 & 48.0 & 0.70894 \\
\hline $17 \mathrm{H}-4,128-150$ & 134.6 & 51.9 & 0.70896 \\
\hline $19 X-4,97-122$ & 145.9 & 53.7 & 0.70890 \\
\hline $21 X-3,125-150$ & 164.1 & 48.9 & 0.70863 \\
\hline $25 X-1,48-84$ & 179.9 & 48.7 & 0.70824 \\
\hline \multicolumn{4}{|l|}{ 344-U1413B- } \\
\hline $1 \mathrm{H}-3,140-150$ & 4.4 & 87.9 & 0.70916 \\
\hline $1 \mathrm{H}-5,60-70$ & 6.2 & 87.3 & 0.70912 \\
\hline $2 \mathrm{H}-5,140-150$ & 14.0 & 83.6 & 0.70913 \\
\hline $3 \mathrm{H}-2,144-154$ & 18.2 & & 0.70905 \\
\hline $3 \mathrm{H}-3,142-152$ & 19.7 & 56.2 & 0.70901 \\
\hline
\end{tabular}

\begin{tabular}{|c|c|c|c|}
\hline $\begin{array}{l}\text { Core, section, } \\
\text { interval }(\mathrm{cm})\end{array}$ & $\begin{array}{l}\text { Depth } \\
\text { (mbsf) }\end{array}$ & $\begin{array}{c}\mathrm{Sr} \\
(\mu \mathrm{M})\end{array}$ & ${ }^{87} \mathrm{Sr} /{ }^{86} \mathrm{Sr}$ \\
\hline \multicolumn{4}{|l|}{ 344-U1413C- } \\
\hline $3 R-1,90-122$ & 188.6 & 49.8 & 0.70837 \\
\hline 5R-1, 116-146 & 208.3 & 57.4 & 0.70841 \\
\hline 7R-2, 77-107 & 228.8 & 64.0 & .70837 \\
\hline 7R-6, 101-131 & 234.5 & 65.6 & .70831 \\
\hline $11 \mathrm{R}-1,114$ & 266.4 & 67.3 & 0.70819 \\
\hline $15 \mathrm{R}-2,103-135$ & 306.1 & 68.9 & .70820 \\
\hline 19R-5, 66-96 & 347.9 & 65.7 & 0.70836 \\
\hline 27R-2, 120-150 & 423.1 & 72.3 & 0.70841 \\
\hline 37R-5, 61-96 & & 73.7 & .70841 \\
\hline $39 R-4,116$ & 2.3 & 72.4 & .70845 \\
\hline $43 R-2,73-$ & .7 & 7.3 & \\
\hline \multicolumn{4}{|l|}{ 344-U1414A- } \\
\hline $1 \mathrm{H}-$ & 0.6 & 4.5 & 70916 \\
\hline $2 \mathrm{H}-3,131$ & 1 & 3.6 & . .70907 \\
\hline $3 \mathrm{H}-2,131-1$ & 14.2 & 3.5 & \\
\hline $5 \mathrm{H}-2,1$ & 33.2 & 0.9 & 12 \\
\hline 7H-2, 140-150 & 52.4 & 75.8 & 916 \\
\hline $9 \mathrm{H}-2,140$ & 71.4 & 84.5 & .70908 \\
\hline $9 \mathrm{H}-5,140-150$ & 75.9 & 85.3 & 70913 \\
\hline $11 \mathrm{H}-5,14$ & & 1.9 & \\
\hline $13 \mathrm{H}-5,1$ & 113.9 & 95.8 & \\
\hline $15 \mathrm{H}-2,140-150$ & 128.4 & 104 & 0.70880 \\
\hline $17 \mathrm{H}-4,135-1$ & 150.3 & 131 & 0.70874 \\
\hline $19 \mathrm{H}-6,135-150$ & 170.7 & 171 & 0.70882 \\
\hline 21 & & 217 & \\
\hline $23 X-5,130-$ & 207.5 & 279 & 379 \\
\hline $24 X-4,94-114$ & 214.9 & 304 & 0.70879 \\
\hline $25 X-2,112-132$ & 222.0 & 318 & 0.70881 \\
\hline $26 \mathrm{X}-5,130-150$ & 236.3 & 358 & 0.70882 \\
\hline $27 X-3,130-1$ & 242.9 & 372 & 0.70881 \\
\hline $28 X-4,67-97$ & 252.9 & 402 & .70882 \\
\hline $30 X-2,79-109$ & 269.4 & 468 & 0.70885 \\
\hline $34 X-1,0-14$ & 302.2 & 494 & 0.70884 \\
\hline $35 X-1,1$ & 308.0 & 710 & .70884 \\
\hline $36 \mathrm{R}-2,67-92$ & 314.0 & 711 & 0.70879 \\
\hline $37 R-3,74-1 C$ & 319.5 & 861 & 0.70869 \\
\hline $38 \mathrm{R}-1,123-145$ & 327.4 & 942 & 0.70865 \\
\hline $38 \mathrm{R}-2,66-102$ & 328.4 & 908 & 0.70869 \\
\hline 39R-1, 80-94 & 336.7 & 904 & 0.70861 \\
\hline
\end{tabular}

